\title{
Therapeutic Outcome of Botulinum Toxin Type A for Patients with Low Bladder Compliance Secondary to Spinal Cord Injury
}

\author{
H. Chen ${ }^{1,2^{*}}$, M. P. Huang1, T. H. Huang1, C. H. Jiang', J. W. Zeng', \\ L. L. Zhou' ${ }^{1}$, Q. L. Liu' ${ }^{1}$, Q. Q. Li ${ }^{1}$, X. Y. Yang1
}

${ }^{1}$ Department of Urology, Guangdong Provincial Work Injury Rehabilitation Hospital and Jinan University, Guangdong, China ${ }^{2}$ Departments of Urology, Qingyan City People’s Hospital, Jinan University, Guangdong, China

Email: *doc.chenhui@163.com

How to cite this paper: Chen, H., Huang, M.P., Huang, T.H., Jiang, C.H., Zeng, J.W., Zhou, L.L., Liu, Q.L., Li, Q.Q. and Yang, X.Y. (2017) Therapeutic Outcome of Botulinum Toxin Type A for Patients with Low Bladder Compliance Secondary to Spinal Cord Injury. Open Journal of Urology, 7, 207-211.

https://doi.org/10.4236/oju.2017.711024

Received: October 4, 2017

Accepted: November 12, 2017

Published: November 15, 2017

Copyright $\odot 2017$ by authors and Scientific Research Publishing Inc. This work is licensed under the Creative Commons Attribution International License (CC BY 4.0).

http://creativecommons.org/licenses/by/4.0/

\begin{abstract}
Objective: To evaluate the efficacy and safety of botulinum toxin type A (BTX-A) in treating patients with low bladder compliance (BC) secondary to spinal cord injury (SCI). Methods: From 2011 to 2016, we retrospected patients who received BTX-A injections for LBC secondary to SCI. The primary outcomes were urodynamic parameters including maximum detrusor pressure (Pdetmax), bladder compliance (BC). Related adverse events were recorded. Results: 72 SCI patients were selected (62 males, 10 females, age range 18 - 52 years; mean age 28.5 years). 12 weeks after BTX-A injection, Pdetmax decreased from $51.02 \mathrm{cmH}_{2} \mathrm{O}$ to $28.31 \mathrm{cmH}_{2} \mathrm{O}$. BC increased from 3.64 $\mathrm{ml} / \mathrm{cmH}_{2} \mathrm{O}$ to $10.08 \mathrm{ml} / \mathrm{cmH}_{2} \mathrm{O} .12$ patients had mild transient haematuria for 1 - 2 days. Conclusion: Intradetrusor BTX-A injection was effective and safe for patients with low BC secondary to SCI.
\end{abstract}

\section{Keywords}

Botulinum Toxin Type A, Low Bladder Compliance, Spinal Cord Injury

\section{Introduction}

Bladder compliance (BC) describes the relationship between the change in bladder volume and change in detrusor pressure [1]. Low BC manifests as a steep rise in detrusor pressure during bladder filling [2]. Sustained detrusor pressure in low $\mathrm{BC}$ has been associated with a high risk factor of upper urinary tract complications, the most dangerous being damage of renal function [3]. Therefore, keeping the detrusor pressure within lower limits has become a primary 
treatment goal for Low $\mathrm{BC}[4]$.

Botulinum toxin A (Botox ${ }^{\circledR}$, Allergan, Irvine, Calif.) has been proven effective in decreasing maximal detrusor pressure for patients with detrusor overactivity (DO) who have an inadequate response to anticholinergic medication [5]. However, to our knowledge, a recent review revealed most data for studies on DO with very little data on Low BC in patients with neurological lower urinary tract dysfunction. Therefore, encouraged by our satisfactory clinical effects, we performed this trail to evaluate the efficacy and safety of BTX-A injections for patients with low BC secondary to SCI.

\section{Method}

This retrospective study reflects 72 SCI impatients from 2011 to 2016. There were 62 males and 10 females, age range 18 - 52 years at first injection, with a mean age of 28.51 years (Table 1$)$. All patients possessed low $\mathrm{BC}\left(<20 \mathrm{ml} / \mathrm{cmH}_{2} \mathrm{O}\right)$ [6] on clean intermittent catheterization, and had an inadequate response to or are intolerant of an anticholinergic medication. All patients were regularly received urodynamic examinations. After informed consent and the approval of the ethics committee, the patients were offered the possibility of BTX-A injection before considering more invasive procedures.

Injections were performed with no anesthesia or under epidural anesthesia in the operating room with a $21 \mathrm{~F}$ rigid cystoscope (Ackermann, Schaffhausen, Switzerland). The bladder was instilled with $100-150 \mathrm{ml}$ sterile saline to achieve adequate visualization so as to avoiding the blood vessels during injections. A 23 gauge needle (Cook Urological Incorporated, Bloomington, IN, USA) was inserted approximately $2 \mathrm{~mm}$ into the detrusor. $200 \mathrm{U}^{\text {Botox }}{ }^{\circledR}$ vials (100 U each) were reconstituted in a total of $30 \mathrm{ml}$ sterile saline $(6.7 \mathrm{U} / \mathrm{ml})$. Patients had 30 1-ml (total $200 \mathrm{U}$ ) injections into the bladder wall, avoiding the trigone (Figure 1) [7]. Procedures were performed by a single senior urologist with extensive

Table 1. Demographic characteristics of the participants.

$\begin{array}{cc}\text { Characteristics } & 72 \\ \text { Number of patients } & 28.51 \pm 18.49 \\ \text { Age, years, mean (SD) } & 61.07 \pm 15.72 \\ \text { Weight (kg) } & 12.02 \pm 6.37 \\ \text { Injury duration, months, mean (SD) } & \\ \text { Neurological injury level, n (\%) } & 2(2.78) \\ \text { Cervical } & 57(79.17) \\ \text { Thoracic } & 13(18.05) \\ \text { Lumbar } & \\ \text { AIS, n (\%) } & 63(87.50) \\ \text { Grade A } & (12.50) \\ \text { Grade B } & \end{array}$

Abbreviations: SCI = spinal cord injury; AIS = American Spinal Injury Association Impairment Scale (AIS). 


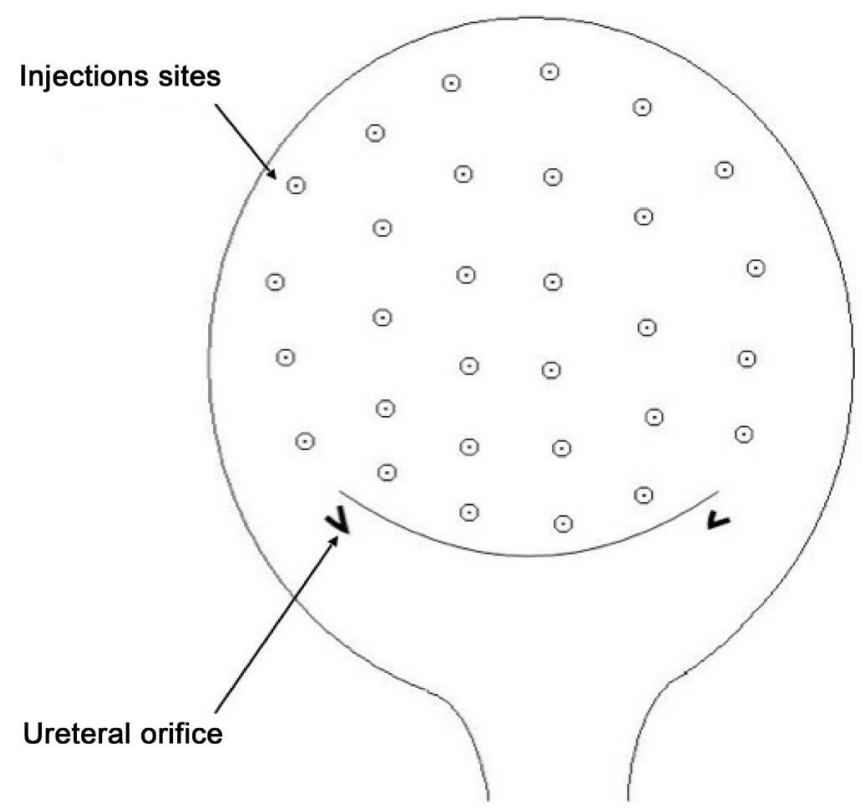

Figure 1. Location of BTX-A injection sites.

experience in BTX-A injections. A catheter had been inserted for 1 - 3 days and antibiotics (except aminoglycosides) were administered for three days.

The follow-up with ultrasound, urodynamics, and clinical evaluation was made at 12 weeks after the procedure. Urodynamic parameters include maximum detrusor pressure (Pdetmax), bladder compliance (BC). Related adverse events were recorded.

Statistical analysis was performed using the SPSS 13.0 soft-ware package (SPSS, Inc., Chicago, IL). Statistical relationships between pre- and postoperative outcome parameters were sought by the Student's t-test for quantitative variables. Statistical significance was considered at $P$ value $<0.05$.

\section{Result}

The results of this study are shown in Figure 2. Pdetmax (Mean maximum detrusor pressure before the injection $51.02 \mathrm{cmH}_{2} \mathrm{O}$, mean Pdetmax after the injection $28.31 \mathrm{cmH}_{2} \mathrm{O}$ ), $\mathrm{BC}$ (Mean bladder compliance, before the injection 3.64 $\mathrm{ml} / \mathrm{cmH}_{2} \mathrm{O}$, after the injection $10.08 \mathrm{ml} / \mathrm{cmH}_{2} \mathrm{O}$ ). During the first week after injection, 12 patients had mild transient haematuria for 1 - 2 days. No patients required medication or surgical intervention.

\section{Discussion}

Low Bladder compliance (BC) commonly occurs in patients with spinal cord injury (SCI). The clinical application of BTX-A is now a common technique in several urological medical fields for neuropathic and non neuropathic patients. BTX-A blocks acetylcholine release by binding, at the presynaptic level, to SNAP-25, a cytoplasmic protein on the cell membrane, which plays a major role in acetylcholine release [7]. BTX-A has been known to reduce signs and symptoms 


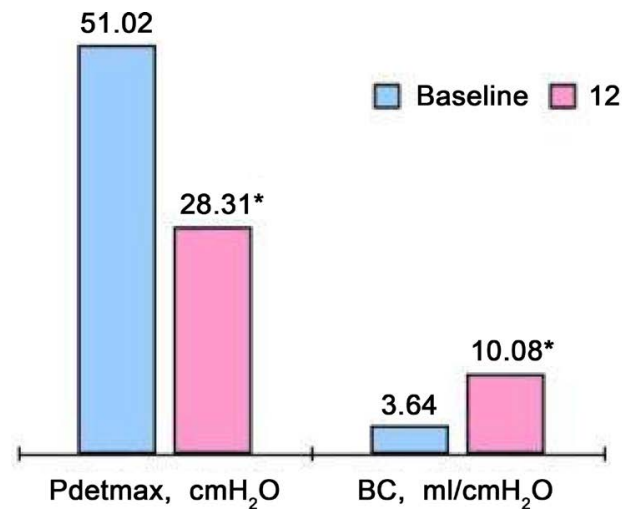

Figure 2. Videourodynamic parameters of patients at baseline and 12 weeks follow-up a significant improvement $\left({ }^{\star} P<0.05\right)$ was noted at 12 weeks.

of neurogenic incontinence, and significantly improve health-related quality of life [8].

In our study, intradetrusor BTX-A injections achieved a low pressure bladder to preserve of the upper tract function for patients with low BC. These findings were supported by improvements in detrusor pressure and bladder compliance. A significant decrease in Pdetmax compared with baseline measurement were observed $\left(28.31 \mathrm{cmH}_{2} \mathrm{O}\right.$ vs $\left.51.02 \mathrm{cmH}_{2} \mathrm{O}, \mathrm{P}=0.041\right)$. Mean Pdetmax reduced to be below $40 \mathrm{cmH}_{2} \mathrm{O}$ at 12 weeks follow up. In 1988, Wang SC [9] reported that for patients with bladder pressures above $40 \mathrm{cmH}_{2} \mathrm{O}, 81 \%$ were potentially dangerous to renal function in five years follow-up. As a result, a significant average increase of $\mathrm{BC}$ (before the injection: $3.64 \mathrm{ml} / \mathrm{cmH}_{2} \mathrm{O}$, after the injection: 10.08 $\left.\mathrm{ml} / \mathrm{cmH}_{2} \mathrm{O}\right)$.

The urodynamic reported changes with botulinum toxin type A monotherapy were translated into significant improvements in health-related quality of life throughout the treatment period. These results imply that the effect of a botulinum toxin type A intradetrusor injection continued during the study period, even without concomitant use of anticholinergics.

In our study, the complications directly related to the BTX-A injection procedure were mild transient hematuria and bladder discomfort during the first week after injection. All patients did not require any medication or surgical intervention.

A limitation of this study is that number of patients was relatively fewer. Therefore, further studies are warranted.

\section{Conclusion}

Intradetrusor BTX-A injection was effective and safe for patients with low BC secondary to SCI.

\section{Acknowledgements}

This study was supported by Medical Scientific Research Foundation of Guangdong Province, China (grant number B2017040). 


\section{Conflict of Interest Statement}

The authors declare no conflict of interest.

\section{References}

[1] Abrams, P., Cardozo, L., Fall, M., et al. (2002) The Standardisation of Terminology of Lower Urinary Tract Function: Report from the Standardisation Sub-Committee of the International Continence Society. Neurourology and Urodynamics, 21, 167-78. https://doi.org/10.1002/nau.10052

[2] Wyndaele, J.J., Gammie, A., Bruschini, H., De Wachter, S., Fry, C.H., Jabr, R.I., Kirschner-Hermanns, R. and Madersbacher, H. (2011) Bladder Compliance What Does It Represent: Can We Measure It, and Is It Clinically Relevant? Neurourology and Urodynamics, 30, 714-722. https://doi.org/10.1002/nau.21129

[3] Gerridzen, R.G., Thijssen, A.M., Dehoux, E., et al. (1992) Risk Factors for Upper Tract Deterioration in Chronic Spinal Cord Injury Patients. The Journal of Urology, 147, 416-418. https://doi.org/10.1016/S0022-5347(17)37254-3

[4] Groen, J., Pannek, J., Castro Diaz, D., Del Popolo, G., Gross, T., Hamid, R., et al. (2016) Summary of European Association of Urology (EAU) Guidelines on Neuro-Urology. European Urology, 69, 324-333. https://doi.org/10.1016/j.eururo.2015.07.071

[5] Schurch, B., de Seze, M., Denys, P., et al. (2005) Botulinum Toxin Type A Is a Safe and Effective Treatment for Neurogenic Urinary Incontinence: Results of a Single Treatment, Randomized, Placebo Controlled 6-Month Study. The Journal of Urology, 174, 196-200. https://doi.org/10.1097/01.ju.0000162035.73977.1c

[6] Stöhrer, M., Goepel, M., Kondo, A., Kramer, G., Madersbacher, H., Millard, R., Rossier, A. and Wyndaele, J.J. (1999) The Standardization of Terminology in Neurogenic Lower Urinary Tract Dysfunction: With Suggestions for Diagnostic Procedures. International Continence Society Standardization Committee. Neurourology and Urodynamics, 18, 139-158. https://doi.org/10.1002/(SICI)1520-6777(1999)18:2<139::AID-NAU9>3.0.CO;2-U

[7] Schurch, B., Stöhrer, M., Kramer, G., Schmid, D.M., Gaul, G. and Hauri, D. (2000) Botulinum-A Toxin for Treating Detrusor Hyperreflexia in Spinal Cord Injured $\mathrm{Pa}$ tients: A New Alternative to Anticholinergic Drugs? Preliminary Results. The Journal of Urology, 164, 692-697. https://doi.org/10.1016/S0022-5347(05)67283-7

[8] Wagner, T.H., Patrick, D.L., Bavendam, T.G., et al. (1996) Quality of Life of Persons with Urinary Incontinence: Development of a New Measure. Urology, 47, 67-71. https://doi.org/10.1016/S0090-4295(99)80384-7

[9] Wang, S.C., McGuire, E.J. and Bloom, D.A. (1988) A Bladder Pressure Management System for Myelodysplasia-Clinical Outcome. The Journal of Urology, 140, 1499-502. https://doi.org/10.1016/S0022-5347(17)42084-2 